\title{
Prevalence of stunting in Iranian children under five years of age: Systematic review and meta-analysis
}

\author{
Kamyar Mansori ${ }^{1,2}$, Fatemeh Khosravi Shadmani ${ }^{3}$, Hossein Mirzaei ${ }^{4}$, Roya Vesal Azad ${ }^{5}$, \\ Sorour Khateri ${ }^{6}$, Shiva Mansouri Hanis ${ }^{7}$, Yousef Moradi $* 8,9$ \\ Received: 23 Jan 2018 \\ Published: 25 Oct 2018
}

\begin{abstract}
Background: Children in all countries, especially in developing countries, constitute a vulnerable group. Therefore, attention to their health issues is very important. The aim of this study was to determine the prevalence of stunting in Iranian children under-five years.

Methods: All original studies were searched by complex search syntax from international databases including Medline (PubMed), Web of sciences, Google scholar, Scopus, CINHAL and the Iranian databases consist of SID (Scientific Information Database, www.sid.ir), Irandoc (Iranian Research Institute for Information Science and Technology, Irandoc.ac.ir), Iranmedex (www.iranmedex.com), and Magiran (www.magiran.com) from January 1989 to August 2017. Two independent reviewers identified relevant studies in several steps. We employed a random effect model to generate a pooled prevalence. The reported prevalence is presented as percent and $95 \%$ confidence interval (CI). Sources of heterogeneity among the studies were determined using subgroup analysis and meta-regression.

Results: Finally, 16 studies from different settings remained for meta-analysis in order to have a pooled prevalence estimate, which prevalence of total stunting was $12 \%(95 \% \mathrm{CI}: 10-14)$. Subgroup analysis for gender showed that the prevalence of stunting in both boys and girls children were equal to $10 \%(95 \% \mathrm{CI}$ : 8-11) and 9\% (CI 95\% 8-10), respectively. Also pooled prevalence of stunting in southern provinces are higher than other provinces.

Conclusion: The prevalence of stunting in some regions of Iran is higher than others. Although, in recent years much effort has been made to address deprivation such as economical, nutritional and social supporting, improvement of the quality of life, there are still nutritional problems in these areas of Iran.
\end{abstract}

Keywords: Prevalence, Stunting, Children under 5 years, Iran

Conflicts of Interest: None declared

Funding: None

*This work has been published under CC BY-NC-SA 1.0 license.

Copyright $\odot$ Iran University of Medical Sciences

Cite this article as: Mansori K, Khosravi Shadmani F, Mirzaei H, Vesal Azad R, Khateri S, Mansouri Hanis Sh, Moradi Y. Prevalence of stunting in Iranian children under five years of age: Systematic review and meta-analysis. Med J Islam Repub Iran. 2018 (25 Oct);32:103. https://doi.org/10.14196/mjiri.32.103

\section{Introduction}

Children in all countries, especially in developing countries, constitute a vulnerable group. Therefore, attention to their health issues is very important. Protein

Corresponding author: Yousef Moradi, moradi.y@tak.iums.ac.ir

1. School of Public Health, Dezful University of Medical Sciences, Dezful, Iran

2. Department of Epidemiology, School of Public Health, Iran University of Medical Sciences, Tehran, Iran

3. Department of Epidemiology, School of Public Health, Shahid Beheshti University of Medical Sciences, Tehran, Iran

4. National Institute of Health Research, Tehran University of Medical Science, Tehran, Iran

5. School of Health, Iran University of Medical Sciences, Tehran, Iran

6. Student Research Committee, Kurdistan University of Medical Sciences, Sanandaj, Iran

7. Social Development \& Health Promotion Research Center, Gonabad University of Medical Sciences, Gonabad, Iran

8. Department of Epidemiology, Iran University of Medical Sciences, Tehran, Iran

9. Student Research Committee, School of Public Health, Iran University of Medical Sciences, Tehran, Iran
Energy Malnutrition (PEM) is a common nutritional problem in children under the age of 5 years $(1,2)$. The PEM in the first years of life leads to growth retardation,

$\uparrow$ What is "already known" in this topic:

Children's health is one of the priorities in most societies. Nevertheless, the highest prevalence rate of stunting occurs among under five-year-old children worldwide. In Iran the prevalence of stunting in studies are different. Therefore, the estimate of the pooled prevalence of stunting is important.

\section{$\rightarrow$ What this article adds:}

The prevalence of total stunting was $12 \%$. This study showed that the prevalence of stunting in Iran's under five-year-old children is high. There are still no overviews addressing this important issue in Iran. Therefore, this result could be of great help to the health sector policymakers to baby's development in embryonic time, growth monitoring and baby nutrition plans. 
stunting, and reduction of the mental development of children with repeated infections, resistance to treatment and reduced physical activity $(3,4)$. The malnutrition is a major cause of reduction of lifetime and pathogens in children, and malnourished children are at higher risk of illness and death than healthy children (5-7). Generally, about $60 \%$ of more than 7 million deaths in under-five children are attributed to malnutrition (8). The malnutrition can have irreversible consequences in the first years of life. In the world, about $25 \%$ of children under the age of 5 suffer from stunting, and it is estimated that $80 \%$ of these children live in developing countries. This is a tragedy for 165 million children under the age of 5 who are suffering from stunting (8). Of every 5 children in developing countries, a child has malnutrition and malnutrition is associated with half of all deaths of children in the world $(5,9)$.

The global estimates of malnutrition indicate that $35.8 \%$ of pre-school children are underweight, $42.7 \%$ of them are stunting, and also $9.2 \%$ are wasting in the developing countries (10). Usually, the WHO standards and NCHS (National Center for Health Statistics) are used to assess child growth and also malnutrition. Initially, WHO (World Health Organization) standards based on Multicenter studies were collected and designed in Brazil, Canada, India, Norway, Oman and America between 1997 and 2003, and in 2006, WHO provided new standards for assessment of child development. The WHO standard includes weight for age, height for age and weight for height and BMI for age for girls and boys 0 to 60 months old (11).

The studies have shown that the prevalence of stunting in children under-five is $26 \%$ in the world, but this figure was $26.8 \%$ in Asia (12). The different studies have been conducted on the prevalence of malnutrition in Iran, but most of these studies are at the provincial level, and studies at the national level are limited. However, the estimated prevalence of these studies are different. For example, the study by Houshiar Rad et al. showed that the prevalence of stunting, underweight and wasting in Iranian children under-five years are 13.1, 7.6, and 4.5\%, respectively(13). Another study in Fars Province (Iran) showed that the rates of stunting, underweight, and wasting are $9.53 \%, 9.66 \%$, and $8.19 \%$, respectively (14). Study of Esfarjani $\mathrm{F}$ et al. showed that the prevalence of stunting is $3.7 \%$ among children in Tehran (15).

Therefore, given that the different prevalence estimated at the provincial and national studies and also the importance of the nutritional status of children under 5 years old as an important health indicator, the aim of this study was to determine the prevalence of stunting in Iranian children under-five years.

\section{Methods}

\section{Search Strategy}

All original articles were searched from international databases including Medline (PubMed), Web of sciences, Google Scholar, Scopus, CINHAL and the Iranian databases consist of SID (Scientific Information Database, www.sid.ir), Irandoc (Iranian Research Institute for Information Science and Technology, Irandoc.ac.ir), Iranmedex (www.iranmedex.com), and Magiran (www.magiran.com) by complex search syntax. We searched in these motor engines and gray literatures without language and time limitation from January 1989 to August 2017. The search performed based on six keywords in English and Persian phrase included Malnutrition, PEM (Protein Energy Malnutrition), Stunting, Growth Disorder, Stunted Growth, Children under 5 years, and children (Table 1).

\begin{tabular}{|c|c|c|c|c|c|c|c|c|}
\hline Authors & Year & $\begin{array}{l}\text { Sample } \\
\text { size }\end{array}$ & Type of study & $\begin{array}{l}\text { Measure- } \\
\text { ments }\end{array}$ & City & $\begin{array}{l}\text { Gen- } \\
\text { der }\end{array}$ & $\begin{array}{c}\text { Prevalence } \\
\text { of } \\
\text { Stunting (\%) }\end{array}$ & $\begin{array}{l}\text { Study } \\
\text { quality }\end{array}$ \\
\hline $\begin{array}{l}\text { Hoshiarzadeh et } \\
\text { al. }\end{array}$ & 2008 & 1417 & $\begin{array}{l}\text { Cross sec- } \\
\text { tional }\end{array}$ & NCHS & Iran & $\begin{array}{l}\text { Male } \\
\text { Fe- } \\
\text { male } \\
\text { Total }\end{array}$ & $\begin{array}{l}14.2 \\
11.8 \\
13.1\end{array}$ & $\begin{array}{l}\text { Moder- } \\
\text { ate }\end{array}$ \\
\hline Emamian et al. & 2011 & 1395 & $\begin{array}{l}\text { Cross sec- } \\
\text { tional }\end{array}$ & NCHS & Semnan & $\begin{array}{l}\text { Male } \\
\text { Fe- } \\
\text { male } \\
\text { Total }\end{array}$ & 10.3 & $\begin{array}{l}\text { Moder- } \\
\text { ate }\end{array}$ \\
\hline Eslamlo et al. & 2012 & 3341 & $\begin{array}{l}\text { Cross sec- } \\
\text { tional }\end{array}$ & NCHS & West Azerbaijan & $\begin{array}{l}\text { Male } \\
\text { Fe- } \\
\text { male } \\
\text { Total }\end{array}$ & $\begin{array}{l}10 \\
7.3 \\
8.7\end{array}$ & $\begin{array}{l}\text { Moder- } \\
\text { ate }\end{array}$ \\
\hline $\begin{array}{l}\text { Shikholeslam et } \\
\text { al. }\end{array}$ & 2008 & 34200 & $\begin{array}{l}\text { Cross sec- } \\
\text { tional }\end{array}$ & NCHS & Iran & $\begin{array}{l}\text { Male } \\
\text { Fe- } \\
\text { male } \\
\text { Total }\end{array}$ & $\begin{array}{c}5 \\
4.4 \\
4.7\end{array}$ & $\begin{array}{l}\text { Moder- } \\
\text { ate }\end{array}$ \\
\hline Naderi Bani et al. & 2012 & 384 & $\begin{array}{l}\text { Cross sec- } \\
\text { tional }\end{array}$ & NCHS & Isfahan & $\begin{array}{l}\text { Male } \\
\text { Fe- } \\
\text { male } \\
\text { Total }\end{array}$ & $\begin{array}{l}21.8 \\
15.7 \\
37\end{array}$ & $\begin{array}{l}\text { Moder- } \\
\text { ate }\end{array}$ \\
\hline Mohammadi et al. & 2010 & 370 & $\begin{array}{l}\text { Cross sec- } \\
\text { tional }\end{array}$ & NCHS & $\begin{array}{l}\text { Sistan and Ba- } \\
\text { luchestan }\end{array}$ & $\begin{array}{l}\text { Male } \\
\text { Fe- } \\
\text { male } \\
\text { Total }\end{array}$ & $\begin{array}{l}10.2 \\
4.5 \\
\\
7.8\end{array}$ & Low \\
\hline Rimaz et al. & 2002 & 1243 & $\begin{array}{l}\text { Cross sec- } \\
\text { tional }\end{array}$ & NCHS & Alborz & $\begin{array}{l}\text { Male } \\
\text { Fe- }\end{array}$ & $\begin{array}{c}8.1 \\
12.1\end{array}$ & $\begin{array}{l}\text { Moder- } \\
\text { ate }\end{array}$ \\
\hline
\end{tabular}




\begin{tabular}{|c|c|c|c|c|c|c|c|c|}
\hline \multicolumn{9}{|l|}{ Table 1. Cntd } \\
\hline \multirow[t]{3}{*}{ Saiedlo et al. } & 2013 & 902 & Cross sectional & NCHS & Isfahan & Male & 9.5 & Moderate \\
\hline & & & & & & Female & 9.2 & \\
\hline & & & & & & Total & --- & \\
\hline \multirow[t]{3}{*}{ Davodi et al. } & 2015 & 1257 & Cross sectional & NCHS & Hamedan & Male & 5.2 & Low \\
\hline & & & & & & Female & 6.3 & \\
\hline & & & & & & Total & 6 & \\
\hline \multirow[t]{3}{*}{ Feshrkinia et al. } & 2008 & 1303 & Cross sectional & NCHS & South Khorasan & Male & 9.4 & Moderate \\
\hline & & & & & & Female & 9.5 & \\
\hline & & & & & & Total & 9.4 & \\
\hline \multirow[t]{3}{*}{ Yarparvar et al. } & 2008 & 500 & Cross sectional & NCHS & Kerman & Male & 3.8 & Moderate \\
\hline & & & & & & Female & 4.8 & \\
\hline & & & & & & Total & 8 & \\
\hline \multirow[t]{3}{*}{ Asfarjani et al. } & 2009 & 137 & Cross sectional & NCHS & Tehran & Male & 5.7 & Moderate \\
\hline & & & & & & Female & 13.4 & \\
\hline & & & & & & Total & 9.5 & \\
\hline \multirow[t]{3}{*}{ Feshrkinia et al. } & 2013 & 480 & Cross sectional & NCHS & South Khorasan & Male & 11.2 & Moderate \\
\hline & & & & & & Female & 8.4 & \\
\hline & & & & & & Total & 7.7 & \\
\hline \multirow[t]{3}{*}{ Sheikhi et al. } & 2011 & 514 & Cross sectional & NCHS & Zahedan & Male & 28.2 & Moderate \\
\hline & & & & & & Female & 22.9 & \\
\hline & & & & & & Total & 25.5 & \\
\hline Authors & Year & Sample size & Type of study & Measurements & City & Gender & $\begin{array}{l}\text { Prevalence of } \\
\text { Stunting (\%) }\end{array}$ & $\begin{array}{l}\text { Study } \\
\text { quality }\end{array}$ \\
\hline \multirow[t]{3}{*}{ Hoshiarzadeh et al. } & 2008 & 1417 & Cross sectional & NCHS & Iran & Male & 14.2 & Moderate \\
\hline & & & & & & Female & 11.8 & \\
\hline & & & & & & Total & 13.1 & \\
\hline \multirow[t]{3}{*}{ Emamian et al. } & 2011 & 1395 & Cross sectional & NCHS & Semnan & Male & ---- & Moderate \\
\hline & & & & & & Female & ---- & \\
\hline & & & & & & Total & 10.3 & \\
\hline \multirow[t]{3}{*}{ Eslamlo et al. } & 2012 & 3341 & Cross sectional & NCHS & West Azerbaijan & Male & 10 & Moderate \\
\hline & & & & & & Female & 7.3 & \\
\hline & & & & & & Total & 8.7 & \\
\hline \multirow[t]{3}{*}{ Shikholeslam et al. } & 2008 & 34200 & Cross sectional & NCHS & Iran & Male & 5 & Moderate \\
\hline & & & & & & Female & 4.4 & \\
\hline & & & & & & Total & 4.7 & \\
\hline \multirow[t]{3}{*}{ Naderi Bani et al. } & 2012 & 384 & Cross sectional & NCHS & Isfahan & Male & 21.8 & Moderate \\
\hline & & & & & & Female & 15.7 & \\
\hline & & & & & & Total & 37 & \\
\hline \multirow[t]{3}{*}{ Mohammadi et al. } & 2010 & 370 & Cross sectional & NCHS & Sistan and Baluchestan & Male & 10.2 & Low \\
\hline & & & & & & Female & 4.5 & \\
\hline & & & & & & Total & 7.8 & \\
\hline \multirow[t]{3}{*}{ Rimaz et al. } & 2002 & 1243 & Cross sectional & NCHS & Alborz & Male & 8.1 & Moderate \\
\hline & & & & & & Female & 12.1 & \\
\hline & & & & & & Total & ---- & \\
\hline \multirow[t]{3}{*}{ Saiedlo et al. } & 2013 & 902 & Cross sectional & NCHS & West Azerbaijan & Male & 5.4 & Moderate \\
\hline & & & & & & Female & 6.4 & \\
\hline & & & & & & Total & ---- & \\
\hline \multirow[t]{3}{*}{ Saiedlo et al. } & 2013 & 902 & Cross sectional & NCHS & Kermanshah & Male & 2.7 & Low \\
\hline & & & & & & Female & 3.3 & \\
\hline & & & & & & Total & ---- & \\
\hline Saiedlo et al. & 2013 & 902 & Cross sectional & NCHS & Isfahan & Male & 9.5 & Moderate \\
\hline & & & & & & Female & 9.2 & \\
\hline & & & & & & Total & ---- & \\
\hline
\end{tabular}

\section{Inclusion/Exclusion Criteria}

We reviewed the search results, and then excluded some studies after reviewing the titles. The evaluation of searched studies was done based on inclusion and exclusion criteria by two reviewers individually (MY, MK). The Preferred Reporting Items for Systematic Reviews and Meta-Analyses (PRISMA) statement was used as a guide to enhance the quality of reporting in this review. In this study, inclusion criteria were 1) cross-sectional design of the study, 2) report of estimated prevalence of Stunting, Growth Disorder, Stunted Growth, Stunting's and PEM in the paper, 3) study on populations younger than 5 years; exclusion criteria were 1) interventional studies and other types of studies except for cross-sectional, 2) animal studies, 3) studies on populations older than 5 years.

\section{Data extraction and Quality assessment}

The qualities of all studies were assessed by Modified Newcastle-Ottawa Scale for cross-sectional studies $(16,17)$ and PRISMA checklist $(7,18-21)$ by two reviewer independently(MY, MH). Under supervision by the reviewing team, checklist including the following factors were filled :1) name of first author, 2) date of publication, 3) date of study, 4) total sample size, 5) sampling method, 6) study design, 7) number of female and male cases, 8) type of questionnaire, 9) score of appraisal tool, 10) main variable, 11) prevalence of malnutrition, stunting, growth disorder, stunted growth, stunting and PEM based on their questionnaire, 12) inclusion criteria. Additional information on study results was extracted with respect to the type of instruments. 


\section{Statistical Analysis}

We employed random effect model to generate a pooled prevalence. The reported prevalence is presented as percent and 95\% confidence interval (CI). The heterogeneity between the included studies will be assessed using the I2 heterogeneity statistic, reported as percentage (\%), to determine the extent of variation between the studies. Forest plot also was used to present result of meta-analysis schematically. Subgroup analysis was conducted on the gender, and geographical region, and meta-regression was performed to examine the impact of year of publication on prevalence.

\section{Results}

Our primary search yielded 242 papers. After reviewing the titles, 132 papers excluded due to duplicating or unrelated papers. From the remained 32 papers, based on the developed checklist articles were excluded (Fig. 1, Table 1). The included papers were categorized in two groups according to their study design (descriptive or analytical cross-sectional studies).

\section{Assessment of Pooled Prevalence}

Finally, 16 studies from different settings remained for meta-analysis. Prevalence of total stunting was $12 \%$ (95\%

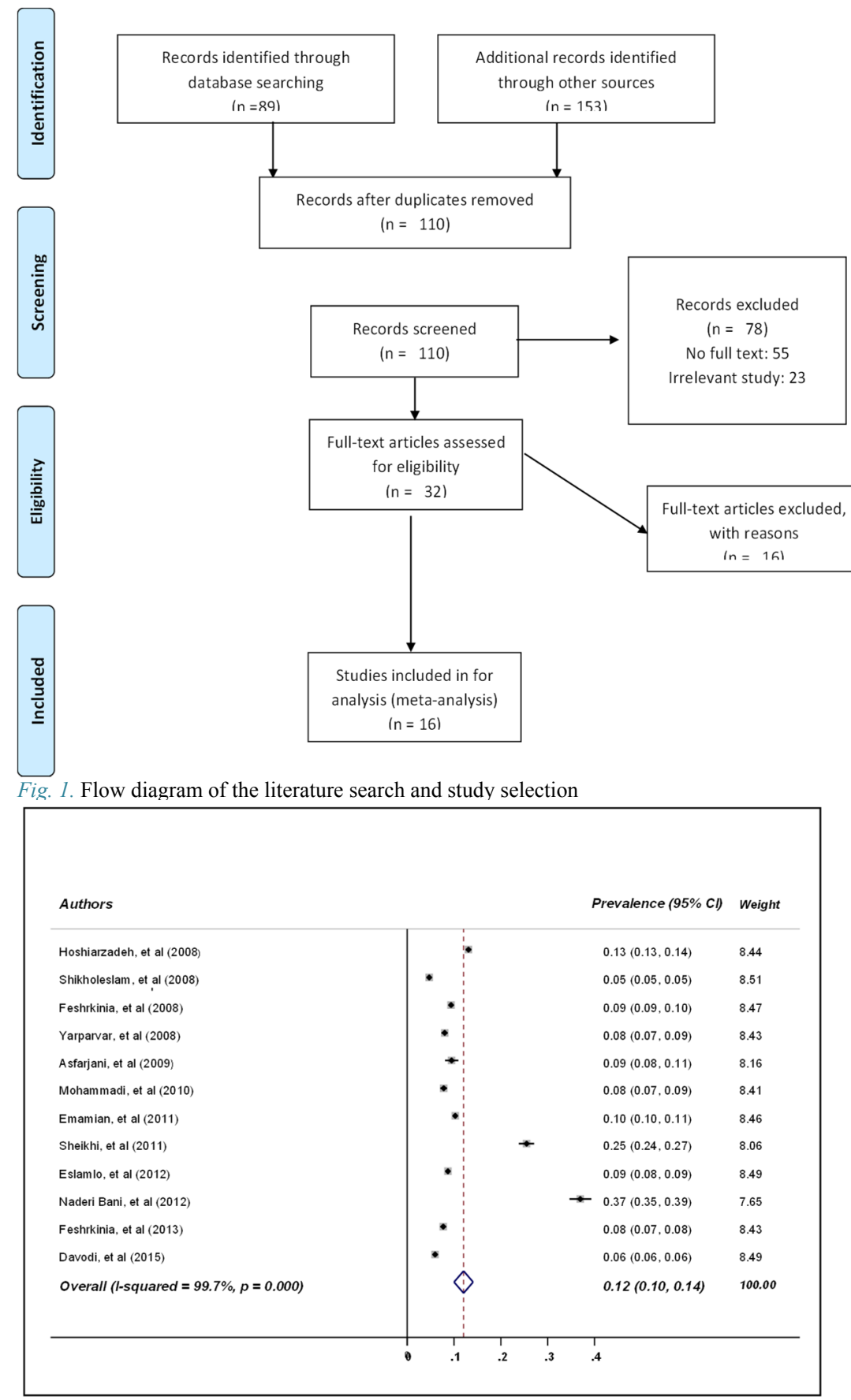

Fig. 2. Meta-analysis of the pooled prevalence of stunting in Iranian children 
CI: 10-14) (Fig. 2). Subgroup analysis for gender showed that the prevalence of stunting in both boys and girls were equal to $10 \%(95 \% \mathrm{CI}: 8-11)$ and $9 \%$ (95\% CI: $8-10)$, respectively (Fig. 3). Also, the estimate of pooled prevalence of stunting based on the subgroup analysis for province in Iran showed that the prevalence in central was $15 \%(95 \% \mathrm{CI}: 10-21)$ and in south was equal to $17 \%(95 \%$ CI: 1-34) (Fig. 4).

\section{Discussion}

The present study was a meta-analysis study which was designed and implemented to determine the prevalence of stunting in Iranian children under-five years. The results of this study showed that the pooled prevalence of stunting in Iranian children under-five years is $12 \%(95 \% \mathrm{CI}: 10 \%-$ $14 \%$ ), regardless of gender. While the subgroup analysis for gender showed that the prevalence of stunting in boys and girls are similar and equal to $12 \%(95 \% \mathrm{CI}$ : $10-14)$. Also, the estimate of pooled prevalence of stunting based on the subgroup analysis for different regions of Iran showed that the prevalence of stunting in western, eastern, southern and central regions are 9\% (95\% CI: 8\%-10\%), $8 \%$ (95\%CI; 7\%-8\%), 17\% (95\%CI: $1 \%-34 \%$ ) and $15 \%$ (95\% CI: $10 \%-21 \%$ ), respectively.

The results of this study showed that the pooled

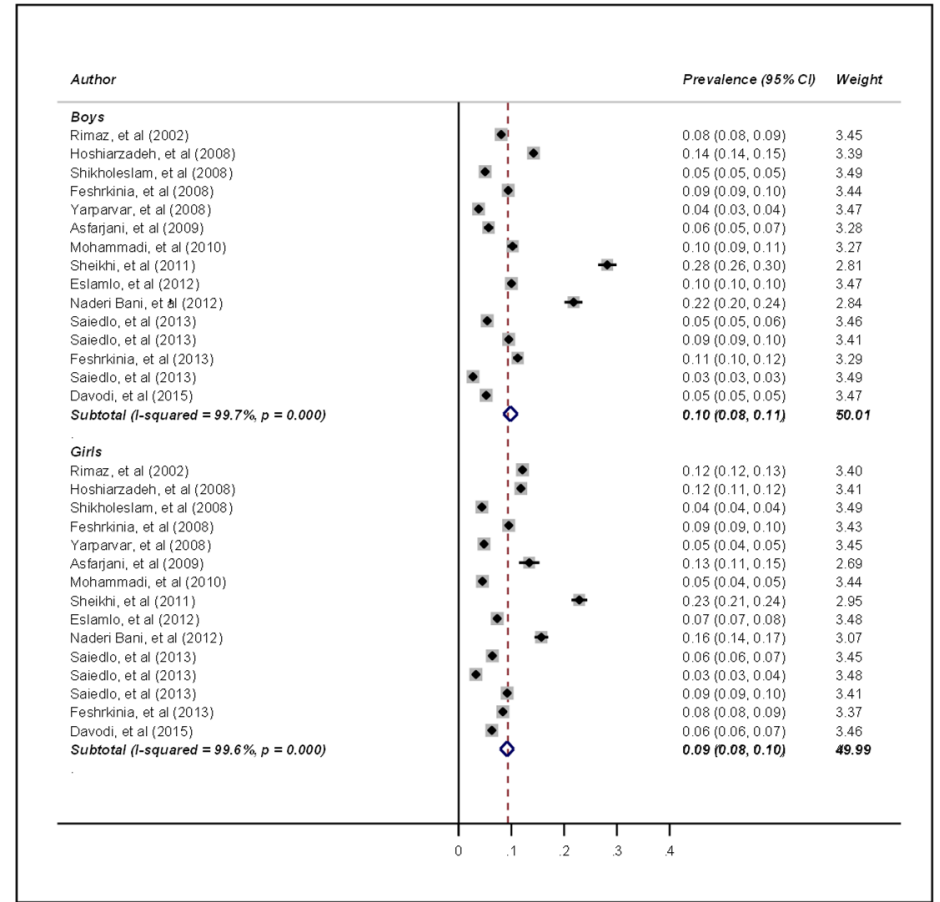

Fig. 3. Meta-analysis of the prevalence of stunting in Iranian children by gender

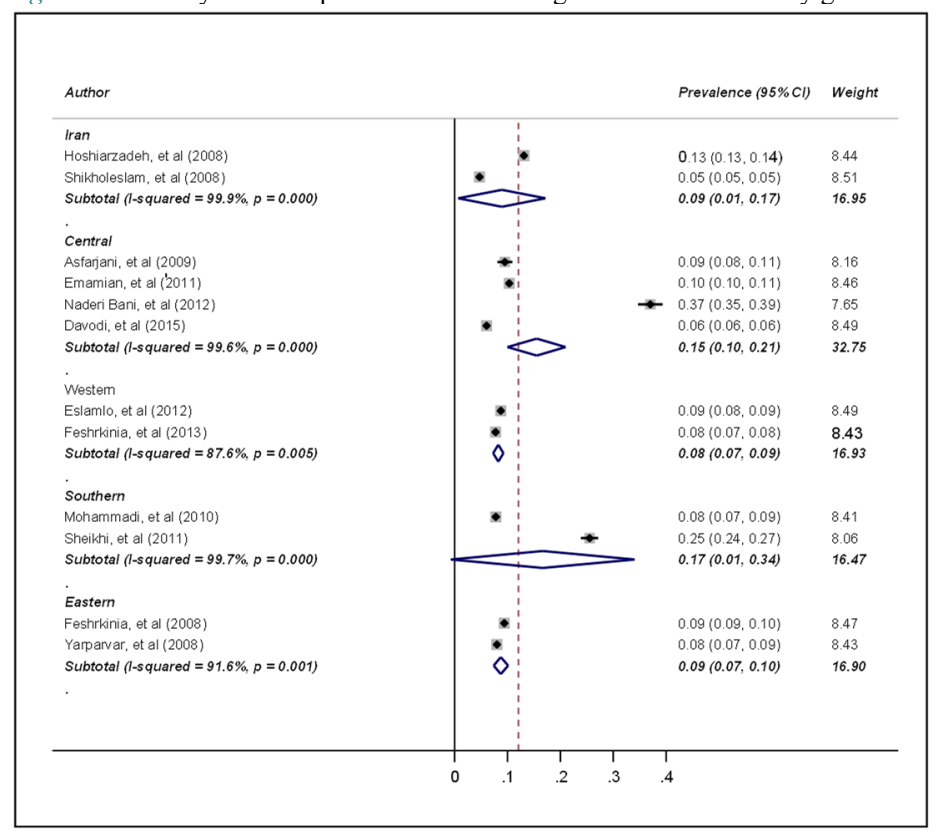

Fig. 4. Meta-analysis of the prevalence of stunting in Iranian children by province 
prevalence of stunting in Iranian children under-five years is $12 \%(95 \% \mathrm{CI}: 10-14)$, regardless of gender. In general, studies are very limited at the national level, and most of the studies in Iran are at provincial and city level. For example, in a national study by Houshiar Rad et al. to determine the prevalence of stunting, underweight, wasting and overweight among Iranian children under five years (2000-2002), a number of 7158 households were selected using systematic sampling from 28 provinces of Iran and, generally, 2562 children were examined. Their results showed that the prevalence of stunting for children under 5 years was $13.1 \%(95 \% \mathrm{CI}: 11.8 \%-14.4 \%)(13)$. As it is seen, the results of this study are not consistent with our study, and the prevalence in our study is almost two times lower; but other studies are more consistent with the results of this study. For example, the data extracted from "Iranian National Study of Malnutrition Prevalence" has showed that prevalence of stunting is $4.7 \%$ in Iranian children in 2008 (22). In another study conducted to investigate the determinants of stunting in first grade primary school children of Tehran, the results showed that the prevalence of stunting is $3.7 \%$ in the study population in 2013 (23). In fact, it can be said that, we are seeing a decrease in the prevalence of stunting in Iran, of course, the decreasing trend of stunting has been reported in South East Asia and world $(24,25)$. This can be explained by improved primary health care during pregnancy and early childhood, breastfeeding and growth monitoring.

In our study, the subgroup analysis for gender showed that the prevalence of stunting in boys and girls are similar and equal to $10 \%(95 \% \mathrm{CI}: 8-11)$ and $9 \%(95 \% \mathrm{CI}: 8-10)$, respectively. The national study by Houshiar Rad et al. to determine the prevalence of stunting, underweight, wasting and overweight among children under five years (20002002), showed that the prevalence of stunting in boys and girls were $14.2 \%(95 \% \mathrm{CI}: 12.2 \%-16.1 \%)$ and $11.8 \%$ (95\%CI: $10.1 \%-13.6 \%$ ), respectively (13). The report of the children's nutritional statusin the provinces of Iran showed that the prevalence of stunting in boys and girls were $16.8 \%$ and $13.9 \%$, respectively (26). A study by Esfarjani et al. showed that the prevalence of stunting in boys and girls are $2.8 \%$ and $4.4 \%$, respectively (23). Most of the studies carried out in this field show that the prevalence of stunting in girls is higher than boys (27-29). This difference may be due to more attention and care of the families to the boys, which is related to the false beliefs and cultural problems of that society (30). Some studies have also shown no significant difference between the two sexes. The study of Nouri Saeidlou showed that stunting rates in girls higher than boys but differences were not significant (8). A study by Davoodi and colleagues showed that there is no significant statistical difference between boys and girls in Hamadan (31).

In the present study, the estimate of pooled prevalence of stunting based on subgroup analysis for different regions of Iran showed that the prevalence of stunting in the western, eastern, southern and central regions are 9\% (95\% CI: 8\%10\%), 8\%(95\%CI: 7\%-8\%), 17\%(95\%CI: 1\%-34\%) and 15\% (95\%CI: 10\%-21\%); respectively. The study by Karajibani et al. in children under six years in Sistan-and-
Baluchestan province which is located in south-east of Iran showed that the prevalence of stunting is $32.1 \%$ (32). The result of a study on the prevalence of malnutrition in children under five years old in Salmas (in west of Iran) showed that the rate of stunting is $7.3 \%$ (8). The study of Davoodi et al. showed that the prevalence of stunting in Hamadan (in west of Iran) was 6\% (31). Also, the study of Fesharakinia in Birjand city (in east of Iran) in 2011 showed that the prevalence of stunting in under 5-year old children is $9.8 \%$ (33). The study of Payandeh with the aim of determination of the prevalence of malnutrition among preschool children in northeast of Iran showed that the rate of stunting was $12.5 \%$ (10). Generally, as can be seen the prevalence of stunting in some regions of Iran is higher. Although, in recent years much efforts have been made to address deprivation such as economical, nutritional and social supporting, improvement quality of life, but there are still nutritional problems in these areas of Iran.

Use of various instruments for measurement of outcomes, inadequate sample size in some studies and various methods for sampling might have increased the risk of information bias and might have been a reason for high heterogeneity in the results of the included studies. In other words, these factors should be investigated in future studies.

The studies have shown that there are many different factors that contribute to child stunting, including poor maternal health and nutrition during pregnancy, anemia in women of reproductive age, child's inadequate nutrition (not eating enough or eating foods that lack growthpromoting nutrients), low birth weight, childhood overweight, exclusive breastfeeding, wasting, and recurrent infections or chronic or diseases which cause poor nutrient intake, absorption or utilization. Specifically, the maternal nutritional and health status before, during and after pregnancy influence child's early growth and development, beginning in the womb. For example, intrauterine growth restriction due to maternal undernutrition is responsible for $20 \%$ of childhood stunting $(33,34)$. Therefore, for the prevention and control of childhood stunting all these factors must be considered.

\section{Conclusion}

In conclusion, it seems that the stunting indicates longterm malnutrition, and in the following years, with the help of adequate nutrition or greater care, education and improved living conditions it can not be reversed easily. So, growth monitoring and baby nutrition plans should be taken into consideration in order to reduce the prevalence of the stunting in Iran.

\section{Conflict of Interests}

The authors declare that they have no competing interests.

\section{References}

1. Javanbakht M, Mashayekhi A, Baradaran HR, Haghdoost A, Afshin A. Projection of diabetes population size and associated economic burden through 2030 in Iran: evidence from microsimulation Markov model and Bayesian meta-analysis. PloS One. 
2015;10(7):e0132505

2. Moradi-Lakeh M, Shakerian S, Yaghoubi M, Esteghamati A, Shokraneh F, Baradaran H-R, et al. Rotavirus infection in children with acute gastroenteritis in Iran: A systematic review and metaanalysis. Int J Prev Med. 2014;5(10):1213.

3. Das S, Rahman RM. Application of ordinal logistic regression analysis in determining risk factors of child malnutrition in Bangladesh. Nutrition journal. 2011;10(1):124.

4. Veghari G. The relationship of ethnicity, socio-economic factors and malnutrition in primary school children in north of Iran: a cross-sectional study. J Res Health Sci. 2013;13(1).

5. Sharghi A, Kamran A, Faridan M. Evaluating risk factors for protein-energy malnutrition in children under the age of six years: a case-control study from Iran. Int J Gen Med. 2011;4:607.

6. Fentaw R, Bogale A, Abebaw D. Prevalence of child malnutrition in agro-pastoral households in Afar Regional State of Ethiopia. Nutr Res Pract. 2013;7(2):122-31.

7. Sobhani S, Asayesh H, Sharifi F, Djalalinia S, Baradaran HR, Arzaghi SM, et al. Prevalence of diabetic peripheral neuropathy in Iran: a systematic review and meta-analysis. J Diabetes Metab Disord. 2014;13(1):97.

8. Nouri Saeidlou S, Babaei F, Ayremlou P. Prevalence of malnutrition in children under 5 years old in Salmas, and comparing to Ravansar and Samirom. Razi j Med Sci. 2014;21(124):47-53.

9. Psaki S, Bhutta ZA, Ahmed T, Ahmed S, Bessong P, Islam M, et al. Household food access and child malnutrition: results from the eight-country MAL-ED study. Popul Health Metr. 2012;10(1):24.

10. Payandeh A, Saki A, Safarian M, Tabesh H, Siadat Z. Prevalence of malnutrition among preschool children in northeast of Iran, a result of a population based study. Glob J Health Sci. 2013;5(2):208.

11. De Onis M, Onyango AW, Borghi E, Garza C, Yang H, Group WMGRS. Comparison of the World Health Organization (WHO) Child Growth Standards and the National Center for Health Statistics/WHO international growth reference: implications for child health programmes. Public Health Nutr. 2006;9(7):942-7.

12. Wessells KR, Brown KH. Estimating the global prevalence of zinc deficiency: results based on zinc availability in national food supplies and the prevalence of stunting. PloS One. 2012;7(11):e50568.

13. Houshiar Rad A, Dorosty A, Kalantari N, Abdollahi M, Abtahi M. Prevalence of stunting, underweight, wasting and overweight among Iranian under-five-year-old children (2000-2002). Iran J Nutr Sci. 2009;3(4):49-56.

14. Kavosi E, Rostami ZH, Kavosi Z, Nasihatkon A, Moghadami M, Heidari M. Prevalence and determinants of under-nutrition among children under six: a cross-sectional survey in Fars province, Iran. Int J Health Policy Manag. 2014;3(2):71.

15. Esfarjani F, Roustaee R, Mohammadi F. Some determinants of Stunting in children of Tehran. Adv Nurs Midwifery. 2012;22(76).

16. Wells G, Shea B, O'connell D, Peterson J, Welch V, Losos M, et al. The Newcastle-Ottawa Scale (NOS) for assessing the quality of nonrandomised studies in meta-analyses. Ottawa (ON); 2009. Available in March. 2016.

17. Wells G. The Newcastle-Ottawa Scale (NOS) for assessing the quality of nonrandomised studies in meta-analysis. http://www.ohri.ca/programs/clinical_epidemiology oxford htm. 2004.

18. David Moher D, Liberati A, Tetzlaff J. Preferred reporting items for systematic reviews and meta-analyses: the PRISMA statement. PLoS Med. 2009;6(7):e1000097.

19. Liberati A, Altman DG, Tetzlaff J, Mulrow C, Gøtzsche PC, Ioannidis JP, et al. The PRISMA statement for reporting systematic reviews and meta-analyses of studies that evaluate health care interventions: explanation and elaboration. PLoS Med. 2009;6(7):e1000100.

20. Haghdoost A, Rezazadeh Kermani M, Sadghirad B, Baradaran H. Prevalence of type 2 diabetes in the Islamic Republic of Iran: systematic review and meta-analysis. East Mediterr Health J. 2009.

21. Moradi Y, Baradaran HR, Yazdandoost M, Atrak S, Kashanian M. Prevalence of Burnout in residents of obstetrics and gynecology: A systematic review and meta-analysis. Med J Islam Repub Iran. 2015;29(4):235.

22. Sheikholeslam R, Naghavi M, Abdollahi Z, Zarati M, Vaseghi $\mathrm{S}$, Sadeghi Ghotbabadi F, et al. Current status and the 10 years trend in the malnutrition indexes of children under 5 years in Iran. Iranian journal of Epidemiology. 2008;4(1):21-8.

23. Esfarjani F, Roustaee R, Mohammadi F, Esmaillzadeh A. Determinants of stunting in school-aged children of Tehran, Iran. Int J Prev Med. 2013;4(2):173.

24. De Onis M, Blössner M. The World Health Organization global database on child growth and malnutrition: methodology and applications. Int J Epidemiol. 2003;32(4):518-26.

25. Abtahi M, Doustmohammadian A, Abbdollahi M. construction of national standards of weight and height and growth charts of iranian children: A review article. Int J Prev Med. 2011;2(3):122.

26. Rath W, Fischer T. The diagnosis and treatment of hypertensive disorders of pregnancy: new findings for antenatal and inpatient care. Dtsch Arztebl Int. 2009;106(45):733.

27. Lisonkova S, Joseph K. Incidence of preeclampsia: risk factors and outcomes associated with early-versus late-onset disease. Am J Obstet Gynecol. 2013;209(6):544. e1-. e12.

28. Smith GN, Walker M, Tessier JL, Millar KG. Increased incidence of preeclampsia in women conceiving by intrauterine insemination with donor versus partner sperm for treatment of primary infertility. Am J Obstet Gynecol. 1997;177(2):455-8.

29. Biswas S, Bose K. Sex differences in the effect of birth order and parents' educational status on stunting: a study on Bengalee preschool children from eastern India. Homo. 2010;61(4):271-6. 30. El Taguri A, Betilmal I, Mahmud SM, Ahmed AM, Goulet O, Galan P, et al. Risk factors for stunting among under-fives in Libya. Public Health Nutr. 2009;12(8):1141-9.

31. Davoodi M, Amini P, Vahidinia A. Evaluation of stunting prevalence and its association to parental education, socioeconomic status and household size of first-grade students in Hamadan, 2012. Pajouhan Sci J. 2015;13(3):58-65.

32. Karajibani M, Shaykhei M, Montazerifar F, Eftekharenia M. Prevalence of Malnutrition in Children under 6 Years in Sistan and Baluchestan Province, Iran. Zahedan J Res Med Sci. 2014;16(8):20-4.

33. Fesharakinia A, Sharifzadeh G. Prevalence of malnutrition in under 5-year old children in Birjand city in 2011. J Birjand Uni Med Sci. 2013;20(1):77-84. 